\title{
Factors Affecting Employees' Work Passion in the Thai Insurance Industry
}

\author{
Boonthipa Jiantreerangkool (corresponding author) \\ National Institute of Development Administration, Bangkok, Thailand \\ 118 Moo3, Serithai Road, Klong-Chan, Bangkapi, Bangkok, Thailand 10240 \\ E-mail: boonthipa@gmail.com
}

Wasita Boonsathorn

National Institute of Development Administration, Bangkok, Thailand

118 Moo3, Serithai Road, Klong-Chan, Bangkapi, Bangkok, Thailand 10240

E-mail:wwasita@hotmail.com

\begin{abstract}
Gary N. McLean
Assumption University, Bangkok, Thailand

592/3 Soi Ramkhamhaeng 24, Ramkhamhaeng Road., Hua Mak, Bangkok, Thailand 10240

E-mail: garynmclean@gmail.com
\end{abstract}

Received: Sep. 4, 2019 Accepted: Oct. 3, 2019 Online published: Oct. 28, 2019

doi:10.5296/ijhrs.v9i4.15398 URL: https://doi.org/10.5296/ijhrs.v9i4.15398

\begin{abstract}
The objectives of this study were to: 1) identify the perceived definition of staff work passion, and 2) explore perceived factors affecting staff work passion, both in the Thai insurance industry. The study was qualitative, using semi-structured interviews with open-ended questions. Participants were 36 key informants from life and non-life insurance companies in Thailand, including executive managers, middle managers, and staff, selected to maximize variation in responses. The definitions of staff work passion in the Thai insurance industry were comprised of five categories: happiness, pride, goal setting, personal efficacy, and job fit. Seven factors affecting work passion were highlighted: 1) the power of teamwork, 2) great support from leader, 3) work value, 4) challenge and variety of work, 5) supportive company
\end{abstract}


policies, 6) gaining knowledge and opportunity to learn, and 7) providing good service to customers. These findings were incorporated into an employee work passion model adapted from Blanchard's model. The model showed personal characteristics of individual as meanings of work passion; organization and job characteristics; and organizational role behaviours as factors affecting work passion. The model might apply to similar businesses within the financial industry, e.g., insurance brokerage companies, financial institutions, and stock and securities firms.

Keywords: work passion, insurance, Thailand

\section{Factors Affecting Employees' Work Passion in the Thai Insurance Industry}

In the current economic climate globally, even the most powerful economies are facing uncertainty about the future (Sachs, 2006). In Asia, the International Monetary Fund (IMF) is reluctant to project stronger growth, especially in Thailand during its period of political transition (IMF, 2017). Businesses face unpredictable economic conditions based on aggressive competition and high consumer-expectations, both domestically and internationally. Thus, they are looking for ways to become more competitive. In Thailand, companies have previously focused on growing the workforce, through mechanization and Thailand 1.0-3.0, as it moves to Thailand 4.0. Now, however, there is a sense that it is time to change the focus. Until now, emphasis has been put on hard strategies, such as mechanization and efficiency. Now, however, there is growth in soft strategies, looking at things once considered intangible, such as workers' feelings toward their work.

\section{Research Questions}

The study was designed to seek perceived meaning and factors affecting staff work passion in the Thai insurance industry. The research questions were: What is the perceived meaning of staff work passion? What are the perceived factors affecting staff work passion in the Thai insurance industry?

\section{Literature Review}

People at work face different scenarios in doing their daily tasks, encountering problems, communicating inside and outside the company, working hard to pursue their goals, and coping with both internal and external environments. They manage those challenges, among others, through their hearts. Passion can be injected into the powerful mind of people by way of increasing their willpower that may transform organizations into accomplishing states.

\subsection{Definitions of Work Passion}

The Ken Blanchard Companies described employee passion as a reaction from a holistic state of comfort, including strategies, policies, processes, production, and executive proceedings (2009). The association revealed an essence of work passion as a positive, passionate state of people arising from "meaningful work, collaboration, fairness, autonomy, recognition, growth, connectedness with leader, and connectedness with colleagues" (The Ken Blanchard Companies, 2009, p. 2). The components contribute to several ideal behaviors encompassed in "discretionary effort, long-term commitment to the organization, peak performance, low 
turnover, and increased tenure with the organization" (The Ken Blanchard Companies, 2009, p. 2).

Vallerand, Robert, Paquet, Philippe, and Charest (2010) and Vallerand (2010) defined passion as an intense desire for activities they like and love, and on which they spend time and expend stamina. Rothbard and Patil (2011) described passion as comparable to engagement, in which the state of mind of an individual operates within a job function and acts as a prominent element for role achievement. Work passion affects an enduring condition of aspiration arising from assessment of the work of an individual (Perrewe, Hochwarter, Ferris, McAllister, \& Harris, 2014). The liking, loving, and valuing of activities in which people invest their energy develops into passionate connection between those activities and one's self (Ho, Wong, \& Lee, 2011).

Dumrongsanti and Boonsathorn (2014) formulated the definition of passion with existing concepts of "commitment, engagement, work passion, and the Buddhist concept of the Path of Accomplishment" (p. 127). Employee work passion is composed of five elements: "intent to stay, striving for excellence, eagerness to learn, exertion and never giving up, and organizational endorsement” (Dumrongsanti \& Boonsathorn, 2013, p. 127).

Perrewe, Hochwarter, Ferris, McAllister, and Harris (2014) defined passion as affecting a constant condition of inclination that occurs from one's assessment of the organization's environment. They synthesized the definition from Vallerand et al. (2010), which stated that passion was an intense persistency to self-evaluating activity that a person likes and values, and to which a person expends pace and strength (Perrewe et al., 2014). Initially, individual love their activities, creating a passionate connection. Later, they reach the point of internalization (Vallerand \& Houlfort, 2003; Ho, Wong, \& Lee, 2011).

Karlsson (2015) described passion as "passion for something" in a circumstance (p. 9) addressed to distinct activity.

Ruiz-Alfonso and Leon (2016) expounded on the meaning of passion as "dedication, persistency, identification with and love of the activity" (p. 1). Work outcomes of passion were positively related to engagement, goal proficiency, good relationships, an encouraging environment, and innovation.

The operational definitional for work passion in this study was the intense feeling of contentment reflected through energy and eagerness toward one's work in line with an individual's particular passion or love for work and related responsibilities, demonstrated by indefatigable persistence (Harter, Schmidt, \& Hayes, 2002; Vallerand, Blanchard, Mageau, Koestner, Ratelle, Leonard, Gagne, \& Marsolais, 2003).

\subsection{Factors Affecting Work Passion}

Philipe, Vallerand, Houlfort, Lavigne, and Donahue (2010) stated that personal relationships within teams and positive emotions were sources of work passion. They carried out studies in three professions: educators, students, and sports teams. They looked for passion in their activities and excellence in social friendships by exploring the roles of emotions as mediators 
(Phillip et al., 2010).

Ho, Wong, and Lee (2011) studied 509 insurance staff and found that work passion occurred from "cognitive engagement comprising attention and absorption" (p. 26). Employees with harmonious passion excel at work with the mediator of cognitive absorption. Cognitive absorption was a composition in cognitive engagement (Rothbard and Patil, 2011). Absorption meant the concentration of the focal spot and preoccupation where individual feel when performing tasks. Obsessive passion showed a negative relationship with "cognitive attention" in the workplace with no effect on work performance (Ho, Wong, \& Lee, 2011, p. 32).

Permarupan, Saufi, Kasim, and Balakrishnan (2013) determined the connection among organization climate, work passion, and organizational commitment by testing 500 professors of private and public universities in Malaysia. There were three propositions related to work passion: higher organizational climate led to higher work passion, there was a positive relationship between organization commitment and employee work passion, and work passion significantly interfered with organizational climate and commitment. A qualitative study led by Umney and Kretsos (2015) from interviewed 30 jazz musicians to explore perceived sources of work passion and found that liking or loving their work, practicing persistently, and improving potential for future employment all increased work passion in their current positions. Ho, Kong, Lee, Dubreuil, and Forest (2018) found that "cooperative psychological climate" assisted in the developing harmonious passion of staff with low intrinsic inclination (p. 122). Hao, He, and Long (2018) affirmed that empowered leadership was an important factor for employee work passion.

\section{Methodology and Methods}

We used a qualitative case study as participants here were employees working in insurance industry in Thailand is particularly effective when managing data collection of people's values and opinions in the social contexts of a specific population (Mack, Woodsong, MacQueen, Guest, \& Namey, 2005). The interview protocol contained 2 open-ended questions that probed respondents' perspectives related to work passion. The nature of open-ended questions allowed the interviewers to receive complete, rich, and insightful information on what might be taking place from the viewpoint of each participant without adding bias through the questions asked (Eisenhardt, 1989; Marshall \& Rossman, 2006). The goal of this activity was to get unique, description-rich data based on participants' experiences, shared openly, while ensuring the anonymity of the informants.

\subsection{Participant Selection}

Participants were selected from 6 life and 15 non-life insurance companies in Thailand, the two major classes of insurance business, using backyard and snowball techniques. Life insurance focuses on life, health, savings, and investment; non-life insurance consists of fire, marine, motor, and miscellaneous. There are 24 life insurance companies in Thailand and 62 non-life insurance companies (Insurance Statistics, 2019). Details about participants are provided in Table 1. 
Table 1. Information about Participants

\begin{tabular}{|c|c|c|c|c|c|c|c|c|}
\hline \multirow[t]{2}{*}{ Code } & \multirow[t]{2}{*}{ Pseudonym } & \multirow[t]{2}{*}{ Gender } & \multirow[t]{2}{*}{ Department } & \multicolumn{3}{|c|}{ Positions in company } & \multicolumn{2}{|c|}{ Companies } \\
\hline & & & & Executive & Middle & Junior & Life & Non-Life \\
\hline $\mathrm{K} 1$ & Katin & $\mathrm{F}$ & Strategic Planning & $\mathrm{I}$ & & & $\mathrm{I}$ & \\
\hline $\mathrm{K} 2$ & Karn & $\mathrm{M}$ & Business Development & & $\mathrm{I}$ & & & $\mathrm{I}$ \\
\hline K3 & Kun & $\mathrm{M}$ & Marketing & $\mathrm{I}$ & & & & $\mathrm{I}$ \\
\hline $\mathrm{K} 4$ & Kamp+B7:B40 & $\mathrm{M}$ & Training and Development & $\mathrm{I}$ & & & $\mathrm{I}$ & \\
\hline K5 & Koya & $\mathrm{F}$ & Underwriting & & $\mathrm{I}$ & & & $\mathrm{I}$ \\
\hline K6 & Kangwan & $\mathrm{F}$ & Health Claim & & & $\mathrm{I}$ & & $\mathrm{I}$ \\
\hline K7 & Kan-pur & $\mathrm{F}$ & Health Claim & & & $\mathrm{I}$ & & $\mathrm{I}$ \\
\hline K8 & King-pai & $\mathrm{F}$ & Marketing & $\mathrm{I}$ & & & & $\mathrm{I}$ \\
\hline K9 & kamen & $\mathrm{F}$ & Business Development & & $\mathrm{I}$ & & & $\mathrm{I}$ \\
\hline K10 & Karn & $\mathrm{F}$ & Sale & $\mathrm{I}$ & & & $\mathrm{I}$ & \\
\hline K11 & Kanta & $\mathrm{F}$ & Underwriting & & & $\mathrm{I}$ & & $\mathrm{I}$ \\
\hline K12 & Kapook & $\mathrm{F}$ & Marketing Support & & $\mathrm{I}$ & & & $\mathrm{I}$ \\
\hline K13 & Kang-han & $\mathrm{F}$ & Customer Service & & $\mathrm{I}$ & & $\mathrm{I}$ & \\
\hline K14 & Kin-jai & $\mathrm{M}$ & Training and Development & $\mathrm{I}$ & & & $\mathrm{I}$ & \\
\hline K15 & Kanom-jean & $\mathrm{F}$ & Product Development & & & $\mathrm{I}$ & & $\mathrm{I}$ \\
\hline K16 & Kiew-bua & $\mathrm{M}$ & Product Development & & $\mathrm{I}$ & & & $\mathrm{I}$ \\
\hline K17 & Kalum & $\mathrm{F}$ & Underwriting & & $\mathrm{I}$ & & & $\mathrm{I}$ \\
\hline K18 & Kao-lad & $\mathrm{F}$ & Human Resource Development & & $\mathrm{I}$ & & & $\mathrm{I}$ \\
\hline K19 & Kwan & $\mathrm{F}$ & Human Resource Development & $\mathrm{I}$ & & & & $\mathrm{I}$ \\
\hline $\mathrm{K} 20$ & Kob-fah & $\mathrm{F}$ & Non-Motor Claim & & & $\mathrm{I}$ & & $\mathrm{I}$ \\
\hline K21 & Kanom & $\mathrm{M}$ & System Devlopment \& Finance & $\mathrm{I}$ & & & & $\mathrm{I}$ \\
\hline K22 & Kamin & $\mathrm{F}$ & Sale \& Marketing & & $\mathrm{I}$ & & & $\mathrm{I}$ \\
\hline K23 & Kaew & $\mathrm{M}$ & Actuary & & & $\mathrm{I}$ & & $\mathrm{I}$ \\
\hline K24 & Kim & $\mathrm{M}$ & Sale & & $\mathrm{I}$ & & & $\mathrm{I}$ \\
\hline $\mathrm{K} 25$ & Khem & $\mathrm{F}$ & Non-Motor Claim & & & $\mathrm{I}$ & & $\mathrm{I}$ \\
\hline K26 & Khan & $\mathrm{F}$ & Non-Motor Claim & & & $\mathrm{I}$ & & $\mathrm{I}$ \\
\hline K27 & Kachin & $\mathrm{F}$ & Non-Motor Claim & & & $\mathrm{I}$ & & $\mathrm{I}$ \\
\hline K28 & Kachen & $\mathrm{F}$ & Non-Motor Claim & & & $\mathrm{I}$ & & $\mathrm{I}$ \\
\hline K29 & Kanoon & $\mathrm{F}$ & Sale \& Marketing & $\mathrm{I}$ & & & & $\mathrm{I}$ \\
\hline K30 & Karit & $\mathrm{M}$ & Claim: Fire, Marine, Motor, Non-Mot & $\mathrm{I}$ & & & & $\mathrm{I}$ \\
\hline K31 & Kanok & $\mathrm{M}$ & Claim: Liability \& Engineering & $\mathrm{I}$ & & & & $\mathrm{I}$ \\
\hline K32 & Koon & $\mathrm{M}$ & Underwriting \& Marketing & $\mathrm{I}$ & & & & $\mathrm{I}$ \\
\hline K33 & Kin & $\mathrm{F}$ & Business Development & $\mathrm{I}$ & & & & $\mathrm{I}$ \\
\hline K34 & Kiri & $\mathrm{F}$ & Sale & & $\mathrm{I}$ & & $\mathrm{I}$ & \\
\hline K35 & Kansorn & $\mathrm{F}$ & Information Technology & & I & & & I \\
\hline K36 & Kampee & $\mathrm{M}$ & Training and Development & & $\mathrm{I}$ & & & $\mathrm{I}$ \\
\hline & & & TOTAL & 13 & 13 & 10 & 6 & 30 \\
\hline
\end{tabular}

\subsection{Data Collection}

In-depth interviews lasted for 50-90 minutes each. In addition to the primary research questions on the meaning of work passion and factors influencing work passion, probing questions were asked of each informant as needed. Interviews were conducted in the workplace or other places based on the preference of each participant. Informed consent was obtained from each participant by signing a consent form based Institute Review Board approval. 


\subsection{Data Analysis}

As the first author typed the transcripts, she was able to recall and review the interviews. She also learned how to improve her interviewing skills for the future. The transcripts were then read through several times. Different colours of highlighters were used to identify common themes, and marginal notes provided reflections about the theme or comment. Once this process was completed several times, the perceived meanings and factors influencing work passion of staff in the insurance industry in Thailand were identified.

We found five meanings of work passion in Thai insurance businesses and seven factors perceived to influence work passion. We grouped those findings into a model with reference to the "Employee Work Passion Model" (Zigarmi, Nimon, Houson, Witt, \& Diehl, 2011, p. 195).

\section{Findings}

The definitions of work passion by staff in the insurance industry in Thailand was grouped into personal characteristics under cognition and affect categories. Cognition indicated the thinking of staff composed of goal setting, personal efficacy, and job fit. Affect included the feeling of people comprised of happiness and pride.

Factors affecting work passion consisted of two themes based on antecedents and consequences: organization and job characteristics and organizational role behaviors. The organization and job characteristics contained six sub-themes: the power of teamwork, great support from leader, supportive company policy, challenge \& variety of works, work value, and gaining knowledge and opportunity to learn. Organizational role behaviors in the insurance industry explored the act of providing excellent services to customers.

\subsection{Definitions}

A summary of the definitions identified by participants is shown in Table 2, followed by detailed explanation of each category.

Table 2. Summary of the Meanings of Work Passion by Staff in the Insurance Industry in Thailand

\begin{tabular}{|c|l|l|c|}
\hline No. & Category & \multicolumn{1}{|c|}{ Description } & Frequency \\
\hline 1 & Happiness & Persons enjoy thinking, speaking, or doing their work responsibility. & 11 \\
\hline 2 & Goal Setting & Individual sets own goals for the accomplishment of work accountability & 10 \\
\hline 3 & Pride & One feels proud in performing and completing their works & 16 \\
\hline 4 & Devotion & People goes extra mile on their work intake & 3 \\
\hline 5 & Job fit & Staff perceive that work characteristics fit their personality, own perception on career path, or other personal views. & 3 \\
\hline
\end{tabular}

\section{Theme 1: Happiness}

Happiness means that people enjoy doing, thinking, speaking, or putting their hands on their work responsibilities. The affection of work was presented as the feelings of an individual. Interviewees reported that contentment was derived from work that fulfilled them together with work that benefits others. The state of mind allowed employees to experience satisfaction due to their execution. Sixteen of the 36 interviewees revealed that they had the 
feeling of happiness, enjoyment, and love in the course of work. Participants said that they feel content, delight, and cheerful plus being honoured to be part of the company.

I felt that performing each claim event which I had never known before made me happy. Then I knew it thoroughly when explaining or transferring information to another person made me feel very proud. (K25/Kachen)

I was very happy doing my own work, no matter the type of work encountered. I was happy to think, do, negotiate, and talk. I enjoy my work truly, which I call passion. (K01/Katin)

\section{Theme 2: Goal Setting}

Accomplishment means the successful point in which individual perceive they reach the designated target. Whenever one felt that they achieved on their goal, they worked with high effort to reach their pre-set goals. Work responsibility in the organization had answered employees' life purposes. They felt happy in the position that company assigns them for. Furthermore, they cared and concerned for the company with belief that they were an important part to incorporate as a major part of the corporate accomplishment. People put their own goals in work career by putting endless effort to work responsibility.

Mr. Kun (K03) raised his own perspective on work passion in his future self.

I set my life goal clearly as a highest point in my life. Work passion defined the present, and even the starting point. I chose to have work passion or end goal as an executive of the marketing department. I wanted to invent new things on the selling side for my company. (K03/Kun)

\section{Theme 3: Pride}

Pride means the feeling of individual who feels proud in performing their work intake. Interviewees took fully responsible on their work intake with full authority to control things or making any decisions with confident. Several of them were assigned to the special projects besides their own job descriptions with trust from executives. They viewed their power in handling or solving problems as keys to push forward integrity of the organization. There were four participants who mentioned about work autonomy as an important ingredient for their work passion.

I was a project manager and lucky that I could control any works on my own e.g. operation, strategy, information technology, and etc. Therefore, it was a challenging project which seeing the result very fast (K03/Kun)

For me, work meant ability to make decision with no hesitance. First, one must be able to think and consider. Two, one needed supportive reasons to back up. (K17/Kalum)

\section{Theme 4: Personal Efficacy}

Personal efficacy means skill, knowledge, ability of individual toward work responsibilities. They worked at their own capabilities with strong belief in their own potential which fully generated to work as much as they can. Attendees performed their jobs on the daily basis by describing their peak performance as excited, energized, cheerful, fire, proud, concentrate, and pressure when executing each piece of work. Thirteen explored their own motive in doing their best tasks to reach high performance level.

In the crisis time after the major floor catastrophe, insurance coverage were limited. Then 
how to renew all those terms with several reinsurers in the market. At the same time, customers must accept new conditions or understand the current situation. Customers would not get the same coverage as they used to get it in the last few years. Anyhow, I must do my best for the new coverage, I tried my best in each accounts and then I found reinsurance companies to support us afterward. (K05/Koya)

It was my own need to thrive for success faster and higher than others...my own urge, motive, and ambitious to do better than someone else. (K16/Kiew-bua)

\section{Theme 5: Job Fit}

Job fit means work characteristics of each individual suits their personality, own perception on career path, or other personal views. For example, works that one: received suitable remuneration, felt that it was easy and comfort, felt that it fit the personality, and had opportunity to learn. Participant expressed their viewpoints toward job descriptions that it pursued them to manage work with full energy. Aspects of work accountability allowed them in truly express themselves on daily works plus any special assignments. The attribution of works in insurance field had enlighten them to reach the state of work passion.

Seventeen said that their work components, combined with their inner self, comprised passion. Work obligations which provided opportunity for them to see various things or new things which differed from their previous experience. They felt gratuity to contribute as a part of the company by combining their characters inside each project responsible. They liked to utilize their experience, knowledge, and strengths to work; together with their non-stop learning in order to create or make better work.

My tremendous happiness in life was that I inspired one person or more. I feel that I had a high value. I liked to help others and responsible in other people. I hate to depend on others. I could not stand to be a burden of others. Like my new model project which created new sale volume which differed from our business segment in the past. People called this project by my name. (K03/Kun)

I was glad to connect with 10 business units in the company like accounting, underwriting, marketing, or all of them; including our own subordinate. (K30/Kawit)

\subsection{Factors Affecting Work Passion}

The second research question was to discover the factors leading to work passion of staff in insurance industry in Thailand. Table 3 provides a summary of the perceived factors affecting work passion, followed by description of each, along with participant quotes.

Table 3. Summary of Perceived Factors Influencing Work Passion

\begin{tabular}{|r|l|l|l|}
\hline No. & $\begin{array}{l}\text { Factors leading to work passion of staff } \\
\text { in insurance industry in Thailand }\end{array}$ & \multicolumn{1}{|c|}{ Description } \\
\hline 1 & The Power of teamwork & Cooperation within team and department where everyone helps each other with same goal on success of the company \\
\hline 2 & Great support from leader & $\begin{array}{l}\text { Roles of leader in organization who acted as navigator, problem solver, supporter, consultant; as well as being a role } \\
\text { model to develop staff with trust sincerely. }\end{array}$ & 17 \\
\hline 3 & Work Value & Works that create meaningful value to others include own self, organization, company, and country. \\
\hline 4 & Challenge and variety of work & Work characteristics that challenge people's ability plus generated opportunity in meeting various type of works and people. \\
\hline 5 & Supportive company policy & $\begin{array}{l}\text { Policy of company which staff in organization accepted or agreed per the pre-settled goals and objectives as follow: fair remuneration, } \\
\text { supportive IT system, nice atmosphere, and compatible's company policy }\end{array}$ & 16 \\
\hline 6 & Gain knowledge and opportunity to learn & Opportunity in learning from job duties related to insurance both inside and outside company. & 11 \\
\hline 7 & Providing good service to customer & Acts of providing and presenting great service to customers at one's best effort, which occurred from inner feeling of employees. & 11 \\
\hline
\end{tabular}


Theme 1: Power of Teamwork and Collaboration

The power of teamwork and collaboration mean cooperation within team and department where everyone helps each other with same goal on success of the company. Employees got along by sharing sincere feeling through effective communication honestly. They trusted each other when working together. Good teamwork could motivate work passion of staff in insurance industry in Thailand. Accomplishment of one person led to team, then team to department, and department to the whole organization.

I and my team always communicated closely. I was lucky that several time when I was handling the project as a business owner, I worked very hard. When I input lot of energy and the work team. Everything was all right in one level, even some parts needed to be changed. Then we solved the problem quickly, and I reviewed feedback to team again. When problem got solved, our premium figure increased. Everyone felt so proud that our tiredness created good results. (K02/Karn)

\section{Theme 2: Great Support from Leader}

Great support from leaders means roles of leaders in organization who acted as navigators, problem solvers, supporters, consultants; as well as being role models to develop staff with trust sincerely. Encouragement of executives in organizations to their staff created work passion. Leaders in working circumstance who encompassed the coaching technique by acting as coaches, helpers, consultants, and problem solvers. They cheered up their staff with fully trust in potential of people. Whenever something went wrong happens in the company, they would take actions in helping subordinates smartly.

Leader was a good example. He worked so hard. He went into the detail of every problems in order to help us solve problems. Employees felt awesome. And he cared for his staff with all activities he created for us. In addition, he remembered everyone and provided rewards when needed. I believed that staff can feel his sincerity. In other workplace, when staff saw the CEO, we might hide. Anyhow, this situation had never happened here, we would run to say hello to him. He always asked us how we were doing. (K33/Kim)

\section{Theme 3: Work Value}

Work value means works that create meaningful value to others include own self, organization, company, and country. Life insurance generated value as life saver when unexpected things happened to human life. It could also protect home, vehicle, and any properties under non-life insurance policies. Staff felt their works had a worthy meaning from their systematic problem solving. They perceived customer's worries very well especially in the difficult time. Several of them agreed that both life and non-life insurance generated great value to others. Working was like helping, this enhanced human spirit in people which was a main source of work passion.

The project I did called new model project in which it inspired several person. Umm, I built something in a project which impact lot of people. It did produce benefits to many people. This was the best thing that happened to me. It was not only my success, it created benefit to 
others from what we built. Thousands of people could gain from this project. (K03/Kun)

Theme 4: Challenge and Variety of Work

Challenging and variety of works mean work characteristics that challenge people's ability plus generated opportunity in meeting various type of works and people. People who answered this matter like to do things on their best effort. Some worked with people outside their own company e.g. IT outsource, agents, brokers; where they brainstormed and exchanged ideas independently for good solutions in things.

I met something new and odd like the variety of my work. It made my work passion raised up. (K32/Kameo)

Talking about this business, we got to talk and exchange knowledge all the time. I said that no one could get succeed alone. I arrived at this position because of friends, brother, sister in this business sector. They helped and supported one another. We were not a permanent competitor or friend forever, anyhow we took turn and learnt from each other. Therefore, it created variety in the competition form in market which we could exchange all the time. (K32/Koon)

\section{Theme 5: Supportive Company Policy}

Supportive company policy means policy of company which staff in organization accepted or agreed per the pre-settled goals and objectives as follow: fair remuneration, supportive IT system, nice atmosphere, and compatible's company policy. Clear mission and vision meant that the company's strategies had supported people's passion on policies and procedures. When staff who worked for the company had an impressive feeling toward company' strategies, policies, system, management, and tools incorporating as the whole organization, then work passion occurred. Vision of board and executives played a crucial point in judging the level of happiness in people.

Staff have positive view on mission and vision, procedure, and policies of their companies. Pictures or actions of employees who acknowledged on company's policy could be reflected on the investment in company's IT system, welfare and benefits of staff, clear directions, and fair payment.

Direction of the boss in becoming number 1 in e-commerce premium of the on-line business. I totally agreed with this. Work supports us to run into the same point by working as a team with the same goal. (K33/Kin)

With vision of executive in seeing the same goal. If all seeing the one goal, we could utilize resources on this way more. More resources generated easier success. (K21/Kanom)

\section{Theme 6: Gaining Knowledge and Opportunity to Learn}

Gaining knowledge and opportunity to learn means opportunity in learning from job duties related to insurance both inside and outside company. In addition, gaining knowledge means people who truly understood their job responsibility truly in order to strive for success of the company. 
Opportunity in learning and deriving knowledge from job were two main reasons which retained talented with the position. One felt fascinated on learning new things from insurance works e.g. underwriting the liability insurance and claim settlement in construction business. For middle and management levels, they exchanged knowledge with people in the industry from seminar, training, and meetings outside the company. Sometimes, joining the conference or meetings with business partnership, e.g., associations, broker companies, and financial institutions could explore the new knowledge plus learning as well.

Main thing for my work passion was learning new things. When knowing more people, I felt that there were something more than what we faced in the company. I learned insurance news from people outside my company. (K05/Koya)

My most passionate thing in working in this field was an underwriting work as I felt that I needed to learn all the time. There were always somethings new happening all the time. (K11/Kanta)

\section{Theme 7: Providing Good Service to Customers}

Providing good service to customers refers to the acts of providing and presenting great service to customers at one's best effort, which occurred from inner feeling of employees. Participants confidently admitted that their happiness from work occurs from customer's happiness. They were proud to be a core centre of customer services with belief that they generated benefits to customers from their work actions or problem solving. Some of them perceived customers as friends with best wishes to assist them in any matters.

Nine respondents who work for claim, marketing, and human resource departments. Several statements from interviewees mentioned that positive customer feedback nurtured them in providing good service. They felt gratuity when hearing compliment or receiving appreciation from customers. They served customers with their hearts, anyhow remain integrity and honesty to company as a work norm.

It was my happiness to hearing compliment from customers. When I provided them good service, helped them or paid claim to them. I felt happy when I needed to explain something and customers listened to me tentatively. I was really happy to relieve their pain. (K25/Khem)

My work passion was answering any inquiries of customers. Customers who contacted us were not coming with no reasons. All of them who came to see us got problems. When problem occurred, we solved it for them completely. Then they came back to say thank you to us in taking care of them nicely. This was my happiness moment, even I serve 50 customers and I heard the nice words from two persons only. (K12/Kapook)

Based on these findings, we created a model, shown in Figure 1. 


\section{MInstitute Macrothink}

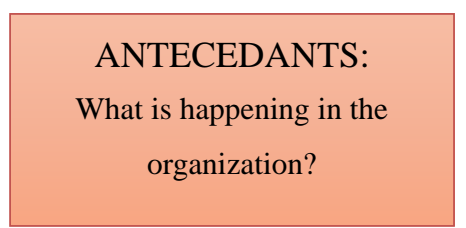

Organization \& Job Characteristics $=$ Factors leading to Work Passion

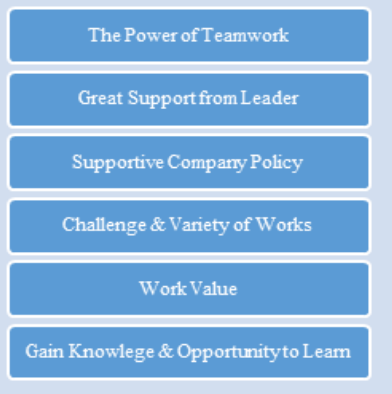

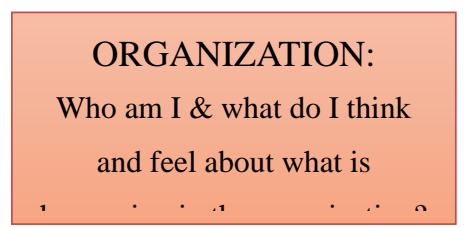

Personal Characteristics $=$ Meaning of Work Passion

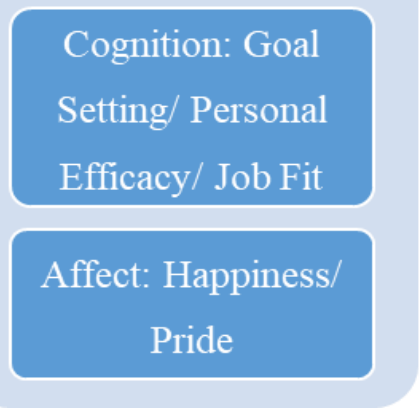

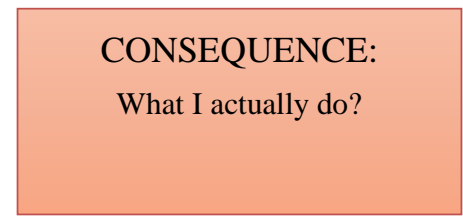

Organizational Role

Behaviors $=$ Factors leading to Work Passion

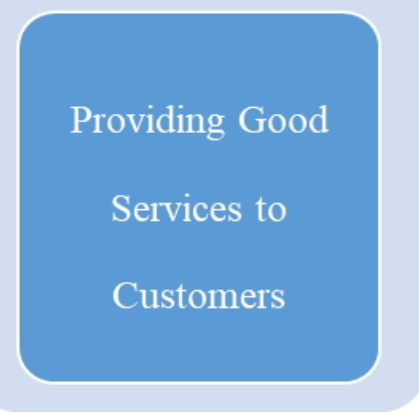

Figure 1. Model of work passion meaning and perceived factors influencing work passion of employees in the insurance industry in Thailand

\section{Discussion}

Work passion is a form of staff engagement in organizations (Cardon, Wincent, Singh, \& Drnovsek, 2009; Gubman, 2004; Mageau, Vallerand, Charest, Salvy, Lacaille, Bouffard, \& Koestner, 2009; Vallerand, Blanchard, Mageau, Koestner, Ratelle, Leonard, Gagne, \& Marsolais, 2003; Vallerand \& Houlfort, 2003). This study focused on work passion of employees in the insurance industry in Thailand. The study was an in-depth analysis of interviews with staff in junior, middle, and senior management positions for maximum variation.

The finding with the highest response on the meaning of work passion was happiness, in alignment with several authors: Gorgievski, Bakker, \& Schaufeli, 2010; Harter, Schmidt, \& Hayes, 2002; Wellins, Bernthal, \& Phelps, 2005. The second ranked meaning was pride, primarily from project managers who responsible for the overall project of the company. This is consistent with Dumrongsanti and Boonsathorn (2014), Gorgievski, Bakker, and Schaufeli (2010), and Inamori (1995). Responsibility of individuals was a meaning of work passion identified by Avery, Mckay, and Wilson (2007). Goal setting is similar to the notion of Cardon, Wincent, Singh, and Drnovsek (2009); Gorgievski, Bakker, and Schaufeli (2010), and Gubman (2004). Personal efficacy can be compared to Maslash and Leiter (2008) who mentioned that work passion occurs from success in life based on individual personal efficacy. Last, job fit was not found in our literature review. Therefore, job fit can be pursued further to find the related perspectives for specific insurance industries in Thailand.

For factors influencing work passion, the top-three ranking results were the power of teamwork, great support from the leader, and work value. With the collectivistic culture of Thailand, colleagues and leaders were very important to employees. Meaningful work was 
another critical factor in creating passion at work (Blanchard, 2009). These results were similar to those of Blanchard (2009); Nimon and Zigarmi (2011); and Zigarmi, Nimon, Houson, Witt, and Diehl (2009). The challenge \& variety of work and gain knowledge \& opportunity to learn were not discovered in our literature. Work value had a similar connotation to the meaningful work mentioned by Zigarmi, Drea, Nimon, Kim, Houson, Dobie, Witt, David, \& Jim (2009), and Nimon and Zigarmi (2014). The last finding, providing good service to customers, took place in the organizational role behaviours or consequences of work passion from employees toward the organization. The insurance industry in Thailand bases its core business on customer service as its business nature, e.g., presenting before purchase; monthly, quarterly, or annual premium collection; and after-sale services on claims processing or risk assessment surveys.

\section{Limitations and Future Research}

Although this study examined several matters on meanings and factors influencing work passion of employees in insurance business in Thailand, there are some limitations to be determined. First, the study took place only in the insurance industry in Thailand with the use of convenience selection and snowball techniques for participant selection, as appropriate for qualitative research. Such research is not intended to be generalized. Second, the use of semi-structure interviewing questions limits the extent of the answers and biases both the answers and the analysis.

Future research might be applied to different business sectors in Thailand, e.g., insurance brokers, financial institutions, securities firms, manufacturing firms, educational institutions, and any other. The research can also be carried out in different countries, possible in some ASEAN emerging countries where Thai industry was their business model, e.g., Myanmar, Vietnam, Cambodia, or Laos. Second, based on the model developed from this research, a post-positivist approach might be used using a survey, allowing for limited generalizability. With such research, gender, age, and experience in the industry can be incorporated as contributing factors. Further, in a post-positivistic study, analysis could compare responses across levels; in this study, we used junior, middle, and senior management. Last, data collection, interviewing, and analysis were carried out by the first author only.

\section{Implications for Theory and Practice}

This qualitative research was designed to contribute to theoretical frameworks of work passion. Based on the findings, we were able to strengthen such theories based on the developed model. To ensure the theoretical validity of the model, additional research is needed, as presented in the last section (Lopez \& Willis, 2004).

For practitioners, applying the outcomes from this study might be useful, especially as a trial. Discoveries in this study showed that employees in this industry found their work passion from relationships with colleagues and the leader. Meaningful work in the workplace leads to work passion. Staff may require clear company policy, opportunity to learn, and challenging work in order to feel work passion. The consequences of work passion include creating excellent customer service that generates fruitful results to the company. 


\section{References}

Avery, D. R., McKay, P. F., \& Wilson, D. C. (2007). Engaging the aging workforce: The relationship between perceived age similarity, satisfaction with coworkers, and employee $\begin{array}{llll}\text { engagement. Journal of Applied Psychology, 92(6). 1542-1556. } & \text { of }\end{array}$ https://doi.org/10.1037/0021-9010.92.6.1542

Blanchard, K. (2009). Leading at a higher level, revised and expanded edition: Blanchard on leadership and creating high performing organizations. Upper Saddle River, NJ: The Ken Blanchard Companies.

Cardon, M. S., Wincent, J., Singh, J., \& Drnovsek, M. (2009). The nature and experience of entrepreneurial passion. Academy of Management Review, 34(3), 511-532. https://doi.org/10.5465/amr.2009.40633190

Csikszentmihalyi, M. (1996). Creativity: Flow and the psychology of discovery and invention. New York: HarperCollins.

Csikszentmihalyi, M. (1997). Finding flow: The psychology of engagement with everyday life. New York: Basic Books.

Dumrongsanti, C., \& Boonsathorn, W. (2014). The importance of passion and factors driving employee passion in creative economy. NIDA Development Journal, 54(3), 125-151.

Eisenhardt, K. M. (1989). Building theories from case study research. Academy of Management Review, 14(4), 532-550. https://doi.org/10.5465/amr.1989.4308385

Gorgievski, M. J., Bakker, A. B., \& Schaufeli, W. B. (2010). Work engagement and workaholism: Comparing the self-employed and salaried employees. The Journal of Positive Psychology, 5(1), 83-96. https://doi.org/10.1080/17439760903509606

Gubman, E. (2004). From engagement to passion for work: The search for the missing person. People and Strategy, 27(3), 42-46.

Hao, P., He, W., \& Long, L. R. (2018). Why and when empowering leadership has different effects on employee work performance: the pivotal roles of passion for work and role breadth self-efficacy. Journal of Leadership \& Organizational Studies, 25(1), 85-100. https://doi.org/10.1177/1548051817707517

Harter, J. K., Schmidt, F. L., \& Hayes, T. L. (2002). Business-unit-level relationships between employee satisfaction, employee engagement, and business outcomes: A meta-analysis. Journal of Applied Psychology, 87(2), 268-279. https://doi.org/10.1037/0021-9010.87.2.268

Ho, V. T., Kong, D. T., Lee, C. H., Dubreuil, P., \& Forest, J. (2018). Promoting harmonious work passion among unmotivated employees: A two-nation investigation of the compensatory function of cooperative psychological climate. Journal of Vocational Behavior, 106, 112-125. https://doi.org/10.1016/j.jvb.2018.01.005

Ho, V., Wong, S., \& Lee, L. (2011). A tale of passion: Linking job passion and cognitive engagement to employee work performance. Journal of Management Studies, 48, 26-47. 
https://doi.org/10.1111/j.1467-6486.2009.00878.x

Inamori, K. (1995). A passion for success. New York, NY: Practical McGraw-Hill Companies. Insurance Statistics: Life Insurance Category (n.d.) retrieved from http://www.oic.or.th/th/consumer/insurance/companies/life/list

Insurance Statistics: Non-Life Insurance Category (n.d.) retrieved from http://www.oic.or.th/th/consumer/insurance/companies/non-life/list

International Monetary Fund (2018). Regional Economic Outlook. Asia Pacific; good time, uncertain times, a time to prepare. World Economic and Financial Surveys. Washington DC.

Karlsson, J. C. (2015). Work, passion, exploitation. Nordic Journal of Working Life Studies, 5(2), 3-16. https://doi.org/10.19154/njwls.v5i2.4790

Liu, D., Chen, X. P., \& Yao, X. (2011). From autonomy to creativity: A multilevel investigation of the mediating role of harmonious passion. Journal of Applied Psychology, 96(2), 294-309. https://doi.org/10.1037/a0021294

Lopez, K. A., \& Willis, D. G. (2004). Descriptive versus interpretive phenomenology: Their contributions to nursing knowledge. Qualitative health research, 14(5), 726-735. https://doi.org/10.1177/1049732304263638

Mack, N., Woodsong, C., MacQueen, K. M., Guest, G., \& Namey, E. (2005). Qualitative research methods: A data collector's field guide. Research Triangle Park, NC: Family Health International.

Mageau, G. A., Vallerand, R. J., Charest, J., Salvy, S. J., Lacaille, N., Bouffard, T., \& Koestner, R. (2009). On the development of harmonious and obsessive passion: The role of autonomy support, activity specialization, and identification with the activity. Journal of Personality, 77(3), 601-646. https://doi.org/10.1111/j.1467-6494.2009.00559.x

Nimon, K., \& Zigarmi, D. (2011). The assessment of a multinational using the employee work passion model. Advances in Developing Human Resources, 13(4), 494-507. https://doi.org/10.1177/1523422311431681

Permarupan, P. Y., Saufi, R. A., Kasim, R. S. R., \& Balakrishnan, B. K. (2013). The impact of organizational climate on employee's work passion and organizational commitment. $\begin{array}{llllr}\text { Procedia-Social and Behavioral } & \text { Sciences, } & 107, & 88-95 .\end{array}$ https://doi.org/10.1016/j.sbspro.2013.12.403

Perrewe, P., Hochwarter, W., Ferris, G., McAllister, C., \& Harris, J. (2014). Developing a passion for work passion: Future directions on an emerging construct. Journal of Organizational Behavior, 35, 145-150. https://doi.org/10.1002/job.1902

Philippe, F. L., Vallerand, R. J., Houlfort, N., Lavigne, G. L., \& Donahue, E. G. (2010). Passion for an activity and quality of interpersonal relationships: The mediating role of emotions. Journal of Personality and Social Psychology, 98(6), 917-932. https://doi.org/10.1037/a0018017 
Rothbard, N. P., \& Patil, S. V. (2011). Being there: Work engagement and positive organizational scholarship. Scholarly Commons, 248, 1-25.Ruiz-Alfonso, Z., \& León, J. (2016). The role of passion in education: A systematic review. Educational Research Review, 19, 173-188. https://doi.org/10.1016/j.edurev.2016.09.001

Ruiz-Alfonso, Z., \& Leon, J. (2016). The role of passion in education: A systematic review. Educational Research Review, 19, 173-188. https://doi.org/10.1016/j.edurev.2016.09.001

Sachs, J. D. (2006). The end of poverty: Economic possibilities for our time. New York, NY: Penguin.

Umney, C., \& Kretsos, L. (2015). "That's the experience": Passion, work precarity, and life transitions among London jazz musicians. Work and Occupations, 42(3), 313-334. https://doi.org/10.1177/0730888415573634

Vallerand, R. J. (2010). On passion for life activities: The dualistic model of passion. Advances in Experimental Social Psychology, 42, 97-193. https://doi.org/10.1016/S0065-2601(10)42003-1

Vallerand, R. J., \& Houlfort, N. (2003). Passion at work. In XX (Ed.), Emerging perspectives on values in organizations (pp. 175-204). Greenwich, CT: Information Age.

Vallerand, R. J., Blanchard, C., Mageau, G. A., Koestner, R., Ratelle, C., Leonard, M., Gagne, M., \& Marsolais, J. (2003). Les passion de I'ame: on obsessive and harmonious passion. Journal of Personality and Social Psychology, 85(4), 756-767. https://doi.org/10.1037/0022-3514.85.4.756

Vallerand, R., Paquet, Y., Philippe, F., \& Charest, J. (2010). On the role of passion for work in burnout: A process model. Journal of Personality, 78, 289-312. https://doi.org/10.1111/j.1467-6494.2009.00616.x

Wellins, R. S., Bernthal, P., \& Phelps, M. (2005). Employee engagement: The key to realizing competitive advantage. Development Dimensions International, 5, 1-31.

Zigarmi, D., Nimon, K., Houson, D., Witt, D., \& Diehl, J. (2011). A preliminary field test of an employee work passion model. Human Resource Development Quarterly, 22(2), 195-221. https://doi.org/10.1002/hrdq.20076

Zigarmi, D., Nimon, K., Houson, D., Witt, D., and Diehl, J. (2009). Beyond engagement: Toward a framework and operational definition for employee work passion. Human Resource Development Review, 8, 300-326. https://doi.org/10.1177/1534484309338171

\section{Copyright Disclaimer}

Copyright for this article is retained by the author(s), with first publication rights granted to the journal.

This is an open-access article distributed under the terms and conditions of the Creative Commons Attribution license (http://creativecommons.org/licenses/by/4.0/). 